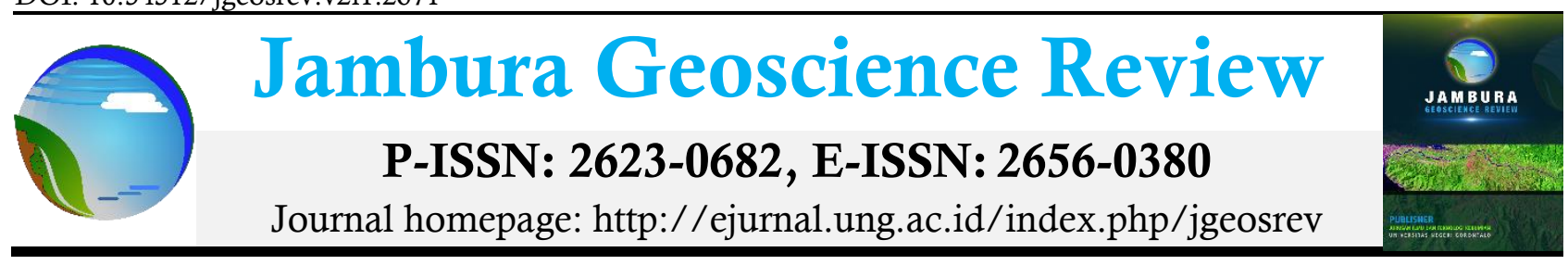

\title{
MAPPING OF LANDSLIDE HAZARD DISTRIBUTION IN ALO WATERSHED GORONTALO REGENCY
}

\author{
Risman Jaya ${ }^{\mathrm{a}}$, Ahmad Syamsu Rijal ${ }^{\mathrm{a}}$ \\ ${ }^{a}$ Geography Study Program, Faculty of Science and Technology, Universitas Muhammadiyah Gorontalo, Jl. Prof. Dr. H. \\ Mansoer Pateda, Telaga Biru 96183, Indonesia
}

\section{ARTICLE INFO}

\section{Article history:}

Received: 21 September 2019

Accepted: 30 November 2019

Available Online: 25 January 2020

\section{Keywords:}

Mapping; Distribution; Landslide;

Scoring; Watershed

Corresponding author:

Risman Jaya

Universitas Muhammadiyah Gorontalo,

Gorontalo, Indoneisa

Email: rismanjaya@umgo.ac.id

\begin{abstract}
Landslide occurrence can be influenced by physical factors and human activities. Thus, research related to the provision of information about landslide distribution in Alo watershed is needed as a basis in enhancing community preparedness in dealing with disasters. The method used in this study is the scoring method based on the Ministry of Public Works Regulation No.22/PRT/M/2017 which is processed through a geographical information system by overlaying all physical parameters. The result shows that the Alo watershed area is divided into three vulnerability categories. "Low" category covers 7171.8 ha, "medium" category covers $12008.7 \mathrm{ha}$, and "high" category covers 5039.5 ha out of 24.221 ha the total area of Alo watershed. Information provided in this research is expected to be able to help the local government in making policies related to the management of Alo watershed area and enhancing the understanding of the local community in Alo watershed in dealing with disasters.
\end{abstract}

Copyright $(2020$ JGEOSREV-UNG This open-access article is distributed under Creative Commons Attribution (CC-BY) 4.0 International license

\section{Introduction}

Natural disasters are a phenomenon that often occurs in Indonesia such as floods, mountain eruptions, earthquakes, and landslides, but the disasters that often occur in the rainy season other than floods are landslides. The assumption of moderate and high rainfall conditions can affect soil stability. Therefore, it is possible to have an impact on the occurrence of land movements (Annisa, et al., 2015). Many articles tried to link the cause and effect of climate change and landslide events. However, there are also articles that highlight that climate factors are not the only determinant in landslide disasters, significant uncertainty between our current understanding of climate linkages and landslide events (Froude \& Petley, 2018). Watershed is an area that greatly contributes to regulating hydrological stability. Significant changes in the watershed area occur as a result of community behavior in terms of land utilization which in the end have a significant impact on landform condition. In addition to those changes, community behavior can also have an impact on the occurrence of a catastrophic disaster which is caused by the decline in the function of the soil and loss of vegetation as a support, a counterweight and a strengthening of land conditions. Inaccurate planning and management of watersheds can have an impact on land degradation or the occurrence of degradation processes that have a negative impact on the watershed. Therefore, it is necessary to supervise the factors that play a role in the use of conservation areas by creating an integrated, comprehensive, sustainable and environmentally sound watershed management approach and involving all aspects of interest (Annisa et al., 2015). 
A landslide is a form of natural disaster that occurs due to the movement of the landmass in large volumes and requires a short amount of time to move material from one place to another place naturally. In general, landslides can occur if the slope of a land reaches $25 \%$ of its sliding plane, semipermeable subsurface, and it receives enough water to move the soil above the sliding plane (Setiawan, Sudarto, \& Putra, 2017) The types of landslides can be classified based on the characteristics of the topographic shape of a land that is a schematic model of a deep landslide which includes rotational slides, planar slides, avalanche debris, and earth flow (Highland \& Bobrowsky, 2008). In another discussion, it is explained that landslides can be defined as downward movement of soil/rock caused and triggered by natural factors such as rock type, landform, rock structure and bedding, slope, soil thickness / weathered material, rainfall and vegetation cover. The process of this movement can occur if the form of sliding, rolling, falling, or flowing (Muntohar, 2010).

In general, the occurrence of landslides is influenced by several factors, namely: Geological factors which include; weak and sensitive rock layer, weathering, rock movement, cracks or joints in rock layers, the difference of rock layers permeability and difference of soil solidity (rigid, solid, plastic). Morphological factors; tectonic or volcanic uplift, ice layer, erosion, changes in slope load position and damage of slope vegetation cover, Physical factors; very high intensity of rainfall, ice melting, long period of rainfall, changes in groundwater-surface, earthquake, volcanic eruption and expansion-shrinkage due to soil weathering, Anthropological factor; slope excavation, deforestation, mining, and artificial vibrations, for example, nuclear experiment TRB, 1996 in (Muntohar, 2010)

The Alo Watershed is administratively located in Tibawa and Pulubala sub-district. This watershed featured total area of $24,221 \mathrm{Ha}$, various slopes, and consists of several types of land cover such as $22 \%$ secondary forest, $3.1 \%$ primary forest, $57 \%$ dry agricultural land, $1.8 \%$ cropland, $15.3 \%$ bush, and 0,2 $\%$ settlement (Jaya, Pomalingo, \& Lihawa, 2016). Land in its use has a capacity limit. Thus, it is necessary to pay attention to the physical condition of land by considering its slope, soil texture, the effective depth of soil, drainage, erosion, physiography, geology and soil type (Adininggar, Suprayogo, \& Wijaya, 2016).

This research aims to provide information related to the distribution of landslide risk in Alo watershed as a basis in the enhancement of community preparedness in dealing with disasters. The threat of landslides always provides bad suggestions for the community, especially in the communities around the Alo watershed area. Landslides in the Alo watershed are influenced by several factors that trigger both the physical condition and the behavior of the farming community that has a role in changing the function of the land in some watershed areas. Thus the need for research on the distribution of landslide events as the capital of public information to increase awareness of future disasters.

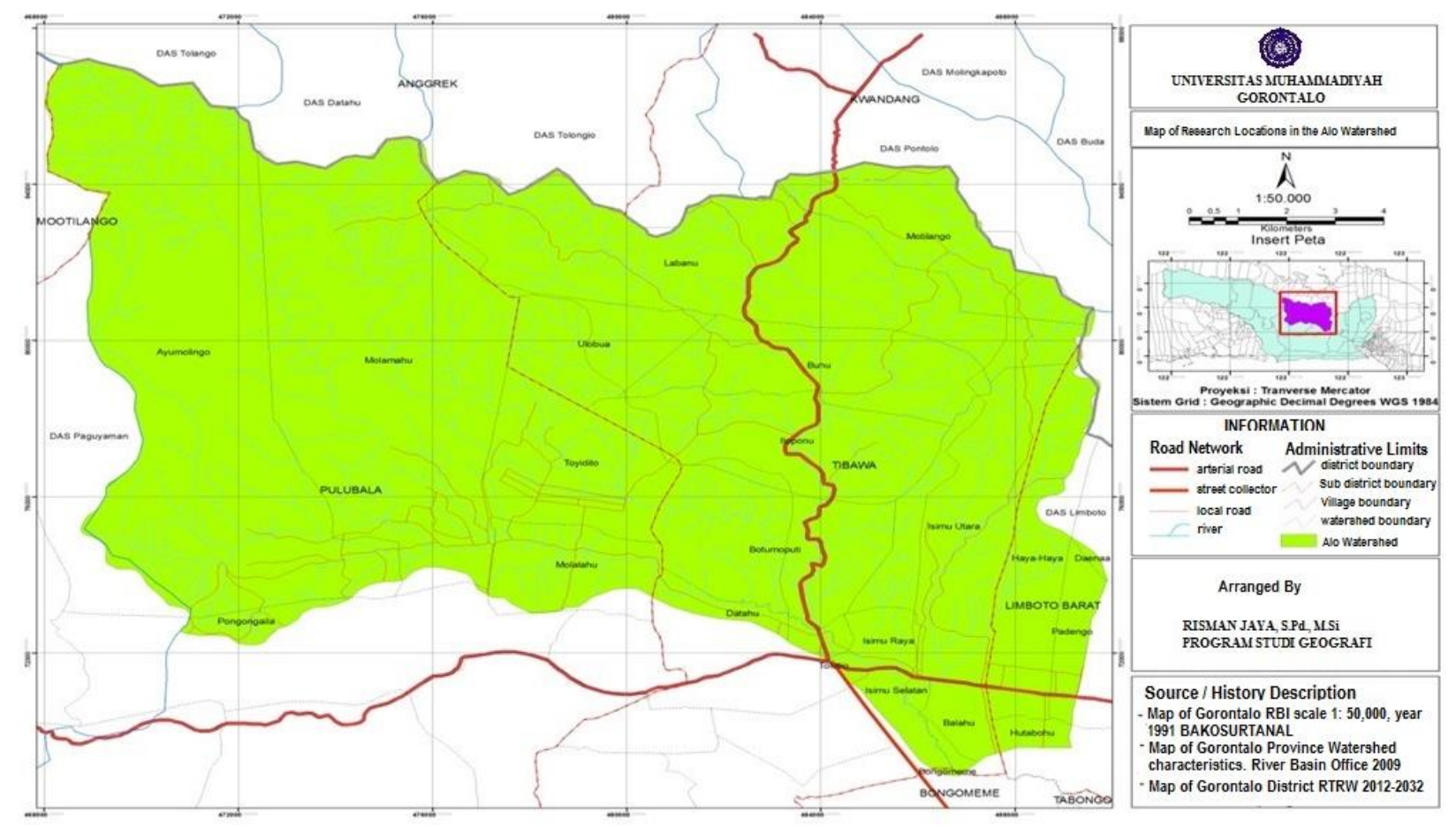

Figure 1. Map of Alo Watershed 


\section{Method}

\subsection{Research Site}

This research was conducted in Alo Watershed, Gorontalo Regency which astronomically located on $00^{\circ} 44^{\prime} 52,715^{\prime \prime} \mathrm{N}$ and $122^{\circ} 49^{\prime} 33,206^{\prime} \mathrm{E}$ to $00^{\circ} 39^{\prime} 59,192^{\prime \prime} \mathrm{N}$ and $122^{\circ} 49^{\prime} 12,778^{\prime} \mathrm{E}$ with a total area of $24,221 \mathrm{Ha}$. The map of the research site is shown in Figure 1.

\subsection{Research Approach and Data Analysis}

This research used a spatial approach in obtaining information related to landslide distribution. The method used in this research was the scoring method (Table 1) which in its implementation was formulated into Geographic Information System (GIS). GIS used to manage physical aspects which later transformed into spatial data such as; slope, geology, soil type, and land use which becomes the parameters and factors in landslide analysis. Vulnerability criteria used in this research was criteria by Menteri Pekejaan Umum No. 22/PRT/M/2017 as follows:
a. 2,40-3,00 categorized as high
b. 1,70-2,39 categorized as medium
c. $1,00-1,69$ categorized as low

Determination of landslide modeling based on spatial requires observation of each parameter in detail. Thus, the determinants of landslide occurences can be concluded. (Chen et al., 2018). Field data accumulation was conducted by direct measuring and analysis of soil movement, basic materials, types and models of landslides and the danger posed by a landslide to the community in Alo watershed on the locations which experienced landslides. Landslides distribution created in the form of a distribution map to provide information related to the areas which are vulnerable to landslides. Thus, community preparedness can be enhanced by finding out areas that are vulnerable to disasters. This research used Schmidt and Fergusson equation (Eq. 1) to obtain $Q$ value as a basis in determining rainfall characteristics.

$$
Q=\frac{\text { Average number of dry months }}{\text { Average number of wet months }} \times 100 \%
$$

\section{Result and Discussion}

Alo river flows naturally in Gorontalo District as one of several important watersheds in terms of the continuation of the hydrological cycle and equality of condition in Limboto Lake. This watershed contributes to influencing Limboto Lake's condition by carrying sediments to Limboto Lake due to the fact that Limboto Lake is the exit gate of this watershed. Historically, Alo watershed experienced landslides which were mainly caused by the social factor in the form of land utilization by the local community and physical factor in form of rainfall, geological characteristics, slope, and soil type. Here are social and physical factors that influence the occurrence of the landslide.

Table 1. Criteria and indicators of vulnerability in landslide potential zone

\begin{tabular}{|c|c|c|c|c|}
\hline Parameters & $\begin{array}{l}\text { Parameters } \\
\text { Score }\end{array}$ & Vulnerability & Score & $\begin{array}{l}\text { The weighted score of } \\
\text { landslide vulnerability }\end{array}$ \\
\hline \multirow{3}{*}{ Slope } & \multirow{3}{*}{$30 \%$} & High & 3 & 0,90 \\
\hline & & Medium & 2 & 0,60 \\
\hline & & Low & 1 & 0,30 \\
\hline \multirow{3}{*}{ Soil type } & \multirow{3}{*}{$15 \%$} & High & 3 & 0,45 \\
\hline & & Medium & 2 & 0,30 \\
\hline & & Low & 1 & 0,15 \\
\hline \multirow{3}{*}{ Slope's rock composition } & \multirow{3}{*}{$20 \%$} & High & 3 & 0,60 \\
\hline & & Medium & 2 & 0,40 \\
\hline & & Low & 1 & 0,20 \\
\hline \multirow{3}{*}{ Rainfall } & \multirow{3}{*}{$15 \%$} & High & 3 & 0,45 \\
\hline & & Medium & 2 & 0,30 \\
\hline & & Low & 1 & 0,15 \\
\hline \multirow{3}{*}{ Vegetation/Land Use } & \multirow{3}{*}{$20 \%$} & High & 3 & 0,60 \\
\hline & & Medium & 2 & 0,40 \\
\hline & & Low & 1 & 0,20 \\
\hline
\end{tabular}

Peraturan Menteri Pekerjaan Umum No.22/Prt/M/2007 
Table 2. Characteristics of average rainfall in Alo Watershed

\begin{tabular}{ll}
\hline Average & Amount \\
\hline Average of annual rainfall in the previous 5 years $(\mathrm{mm})$ & 1359,02 \\
Average of maximum rainfall in the previous 5 years $(\mathrm{mm})$ & 147,66 \\
Average of minimum rainfall in the previous 5 years $(\mathrm{mm})$ & 16,04 \\
Average of wet months (month) & 5,8 \\
Average of humid months (month) & 2,2 \\
Average of dry months (month) & 4 \\
\hline
\end{tabular}

The results of the 2019 analysis based on BMKG online data in the past 5 years

\subsection{Rainfall}

High-intensity rainfall can induce pore water pressure in the soil so that pressure occurs by liquids which later cause mutually separating motion between aggregates of rock or soil material that moves down the slope due to water flow in the gliding field which provides a hydraulic boost. Thus, landslides occur due to the decrease in soil and land stability (Susanti et al., 2012). Based on the management of rainfall data in the last 5 years, it is known as a matter of years that describes the rainfall conditions in the Alo watershed area. Rainfall observation station is in a radius of 1 to $6 \mathrm{~km}$ from landslides. The highest rainfall occurred in January with an average intensity of $193.04 \mathrm{~mm}$ and in May with an average intensity of $194.52 \mathrm{~mm}$. Here are the characteristics of rainfall data.

Based on Table 2 and the results of a calculation using the Schmidt and Ferguson equation, it is obtained the value "Q $=68.96 \%$ " where the value is included in type $\mathrm{D}$ with the provision of having "moderate" rainfall. Within a span of 5 years with the intensity of "moderate" rainfall resulted in 9 landslide events and land movements that are distributed in the Alo Watershed of Gorontalo Regency. Based on the scoring of monthly rainfall which is accumulated into 2018 total rainfall data and analyzed using Geographic Information System, rainfall in the study site is in the "medium" and "high" category (Figure 2). In general, an area in Alo watershed is dominated by "medium" proven by the result of calculation using Schmidt and Ferguson's equation that shows " $\mathrm{Q}=68.96 \%$ ". Therefore, rainfall is not the main factor of landslide occurrence in Alo watershed.

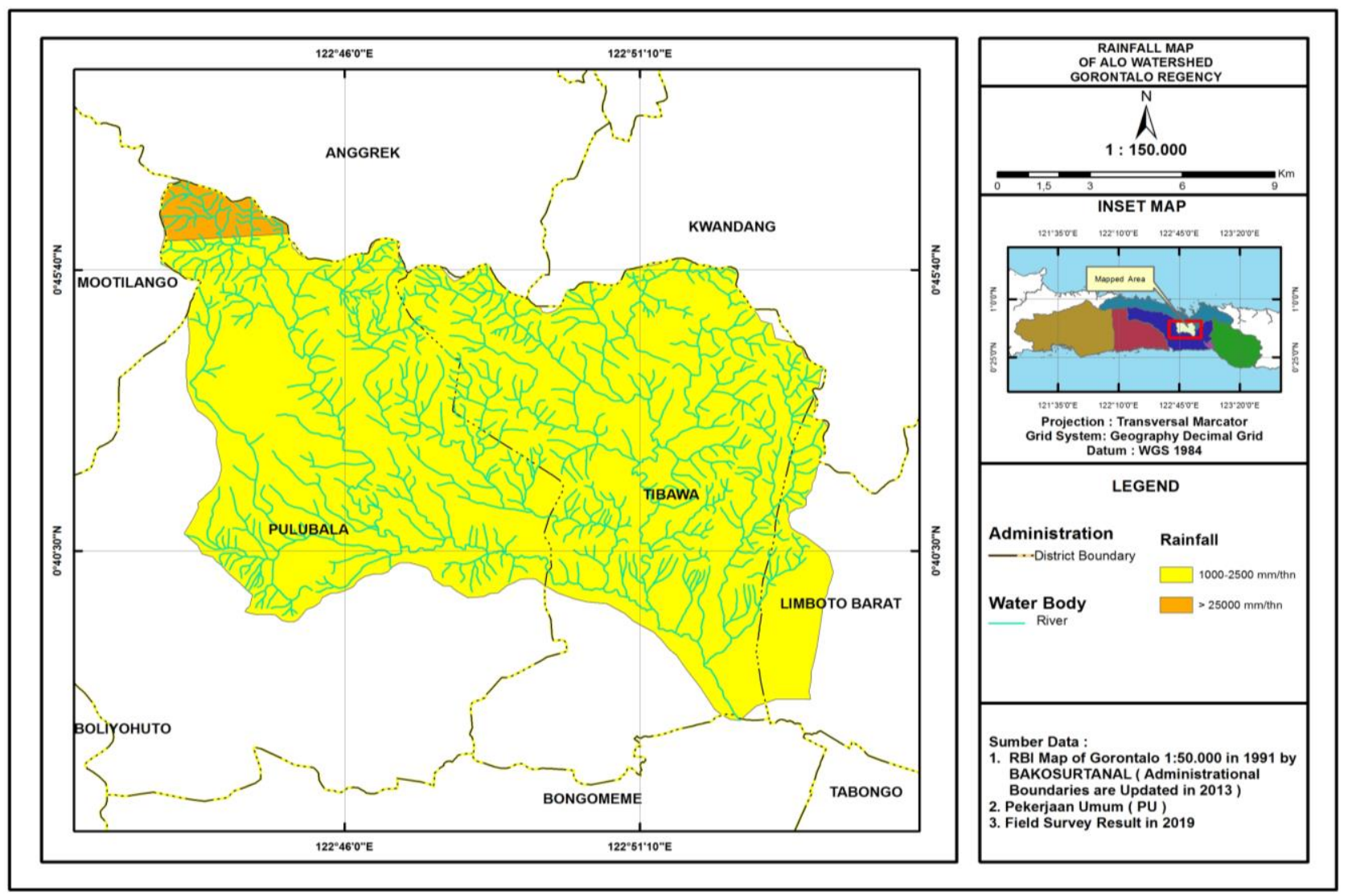

Figure 2. Map of rainfall conditions in the Alo Watershed 


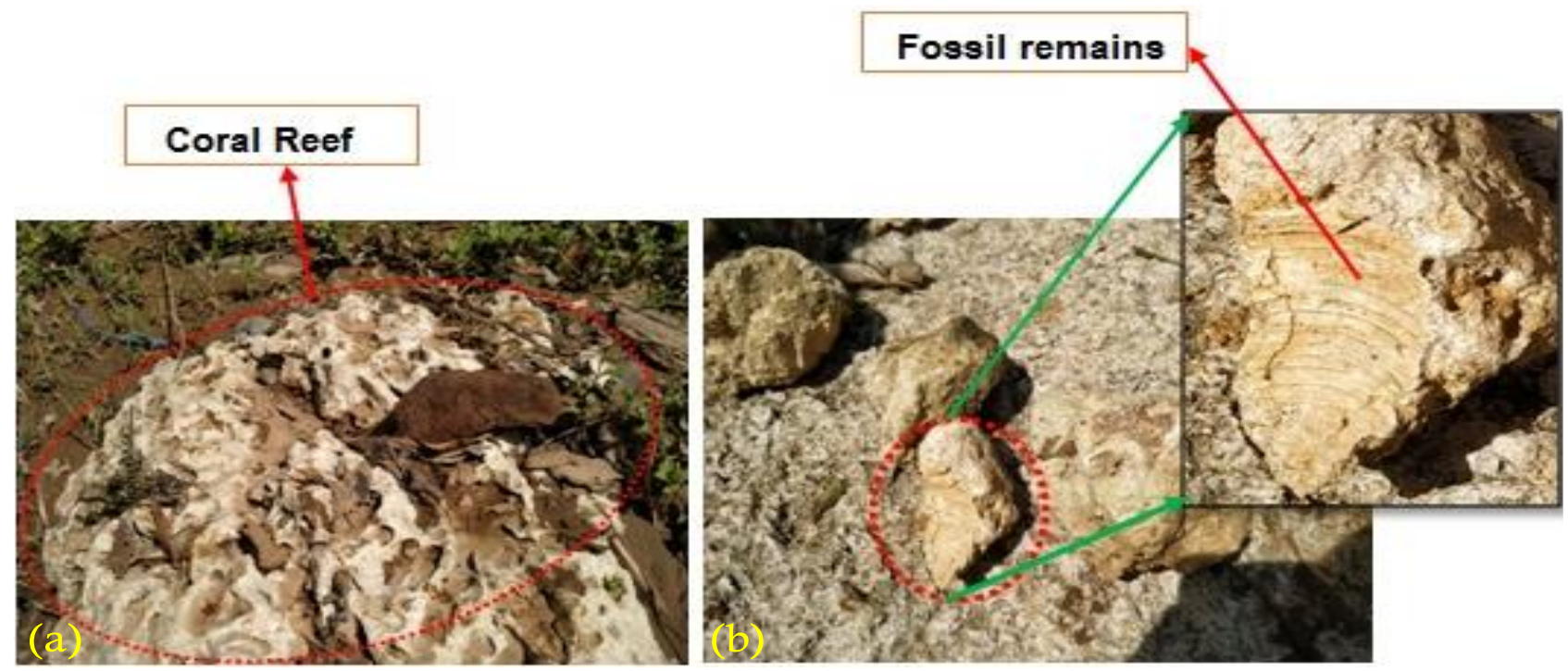

Figure 3. (a) Reef limestone and (b) Fossil remains in limestone

\subsection{Rock and Geological Characteristics}

Alo watershed has various geological conditions which can be seen from the characteristics of rock types that are distributed throughout the watershed. Landslides that affect the physical landscape and landform changes can affect the condition of the Alo Watershed. Geological conditions can not be separated from its lithological conditions, where lithological conditions are very influential in the occurrence of landslides. The following is one of the conditions and types of rocks found at the study site.

The condition of the rocks obtained is based on field observations and identification processes on the types of rocks obtained at the study site. The rock type in (Figure 3) was obtained at the first sample location at coordinates N 0040 '21.3 and E $122^{\circ} 51$ ' 24.7 ". In Figure 3a is a type of reef limestone, this rock is the result of the release of the cliff when landslides occur and are deposited in Alo riverbanks. Figure $3 b$ is a type of coral limestone, some evidence can be observed on these rocks which have ancient fossil marks. Types of limestone and corals found are rocks that have undergone weathering processes due to chemical factors and are located on the cliffs that have been discharged by the Alo river stream, causing a rotational landslide.

Table 3 describes the state of lithology distributed in Alo watershed area from several rock formations which are composed of sedimentary rocks and surface sedimentary rocks, volcanic rocks, and extrusive rocks. The spatial distribution of rock types can be observed (Figure 4).

\subsection{Slope}

The slope is one of the parameters that affect the occurrence of landslides. Landslide is more likely to occur on a steep and long slope. The more steep and longer the slope, it is more likely for landslides to occur. Based on the slope at the study site shown in Figure 5. Whereas, there are land changes due to misuse such as excessive land-use change activities by farming communities on a steep slope that it

Table 3. Distribution of rock types in Alo Watershed

\begin{tabular}{|c|c|c|c|}
\hline No & Rock type & Area $(\mathrm{Ha})$ & Percent $(\%)$ \\
\hline 1 & TQ1; Kalkarenit, kalsirudit, coral limestone & 3410.6 & 14.1 \\
\hline 2 & TQpv; Lapilli tuff, breccia and lava & 343.1 & 1.4 \\
\hline 3 & Tmb; Diorit, diorit kuarsa, granodiorit, adamelit & 5710.1 & 23.7 \\
\hline 4 & $\begin{array}{l}\text { Tmd; Wake sandstone, siltstone, mudstone, conglomerate, tuff, } \\
\text { lapilli tuff, agglomerate }\end{array}$ & 4837.97 & 20.1 \\
\hline 5 & Q1; Limestone, Lifted Reef and Klastik Limestone & 344.2 & 1.4 \\
\hline 6 & Tmbv; Breccias, tuffs and andesite to basalt lava & 7927.1 & 33 \\
\hline 7 & Qpl; Gray claystone, fine-grained to coarse sandstone and gravel & 1533.9 & 6.4 \\
\hline \multicolumn{2}{|c|}{ Total } & 24106.03 & 100 \\
\hline
\end{tabular}




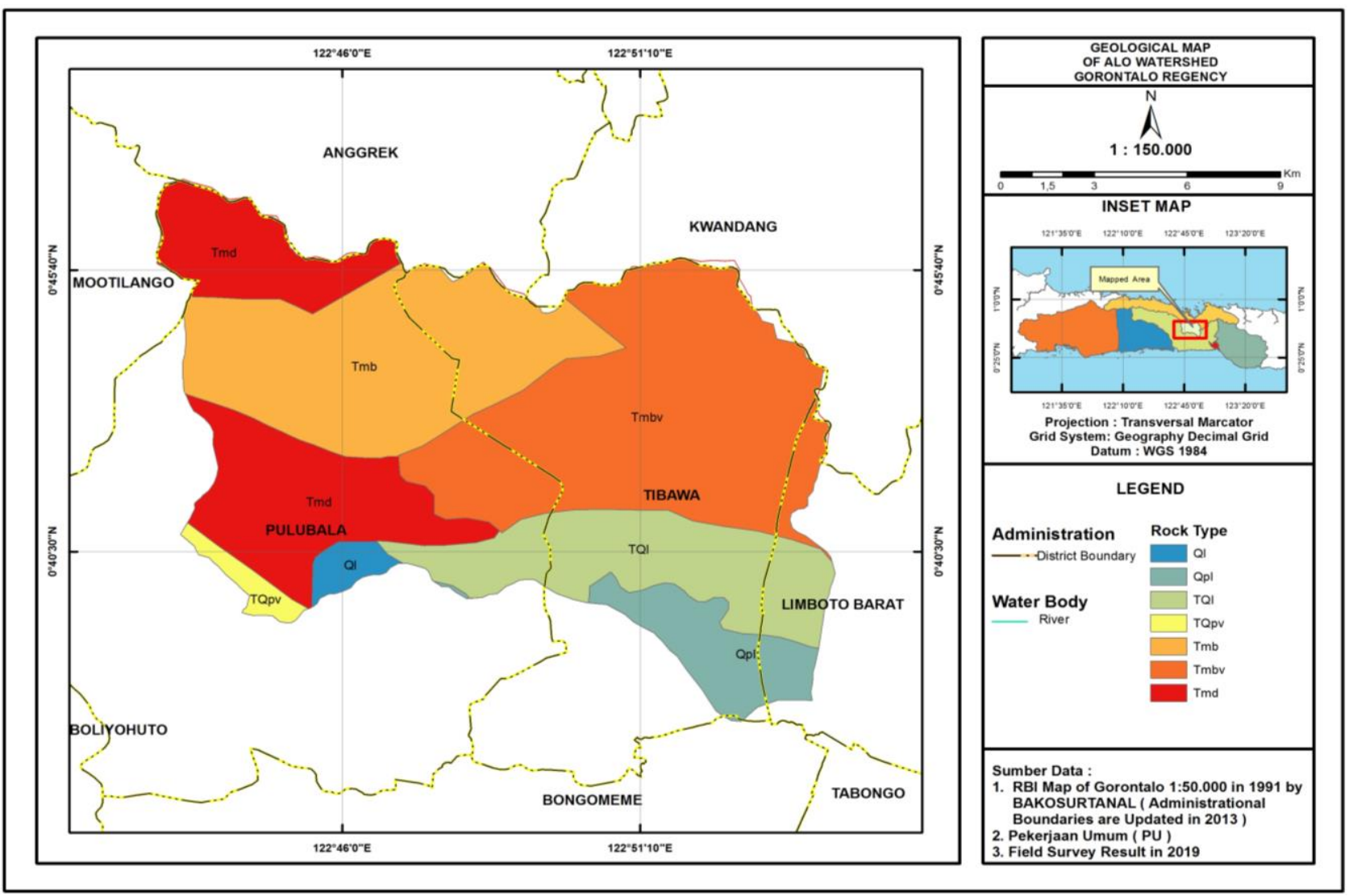

Figure 4. Distribution of geological characteristics in the Alo Watershed

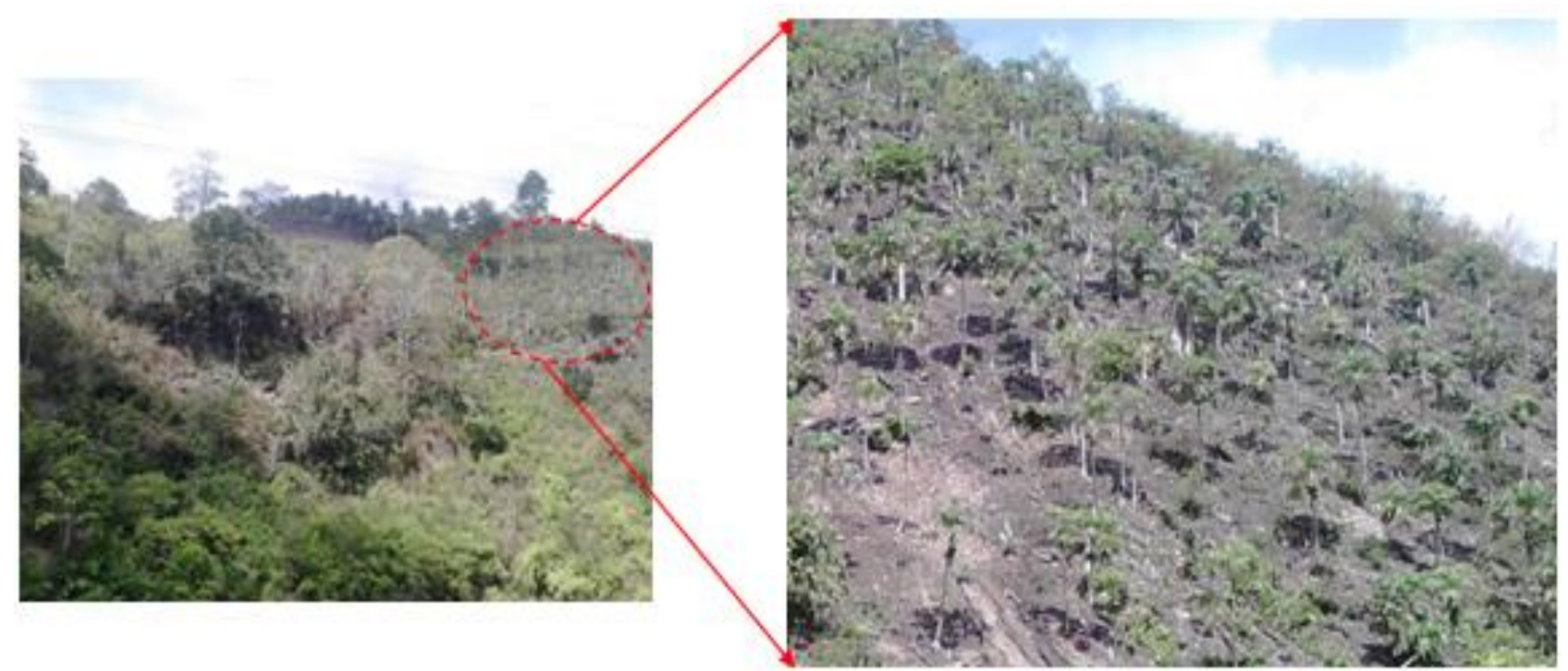

Figure 5. Hill with a slope $>25 \%$ which is converted into a papaya plantation

leads to land degradation due to erosion and eventually damaging the land. As a result of improper utilization, it triggers landslides on land with a slope of $25-40 \%$. This can be supported based on surveys and field observations which showed that $90 \%$ landslides at the research location are occurred at area with $>25 \%$ of slope with various types of landslides.

The existence of vegetation also becomes a very influential factor. Based on the results of the field survey, the landslide occurred in an area that has experienced land conversion. Land conversion is intended to convert hills with a slope of $>25 \%$ (Figure 5) to plantation land and seasonal agriculture, such as corn, papaya, and peanuts as well as the cultivation of teak trees. The morphological distribution in the Alo watershed is classified into 5 classes namely $0-8 \%, 8-15 \%, 15-25 \%, 25-40 \%$ and $>$ $40 \%$ (Figure 6). High landslide susceptibility classes are caused by areas that have high landslide susceptibility and are supported by slope $>30 \%$ which tends to be unstable towards land stability (Asiki, Maryati, \& Akase, 2019). 


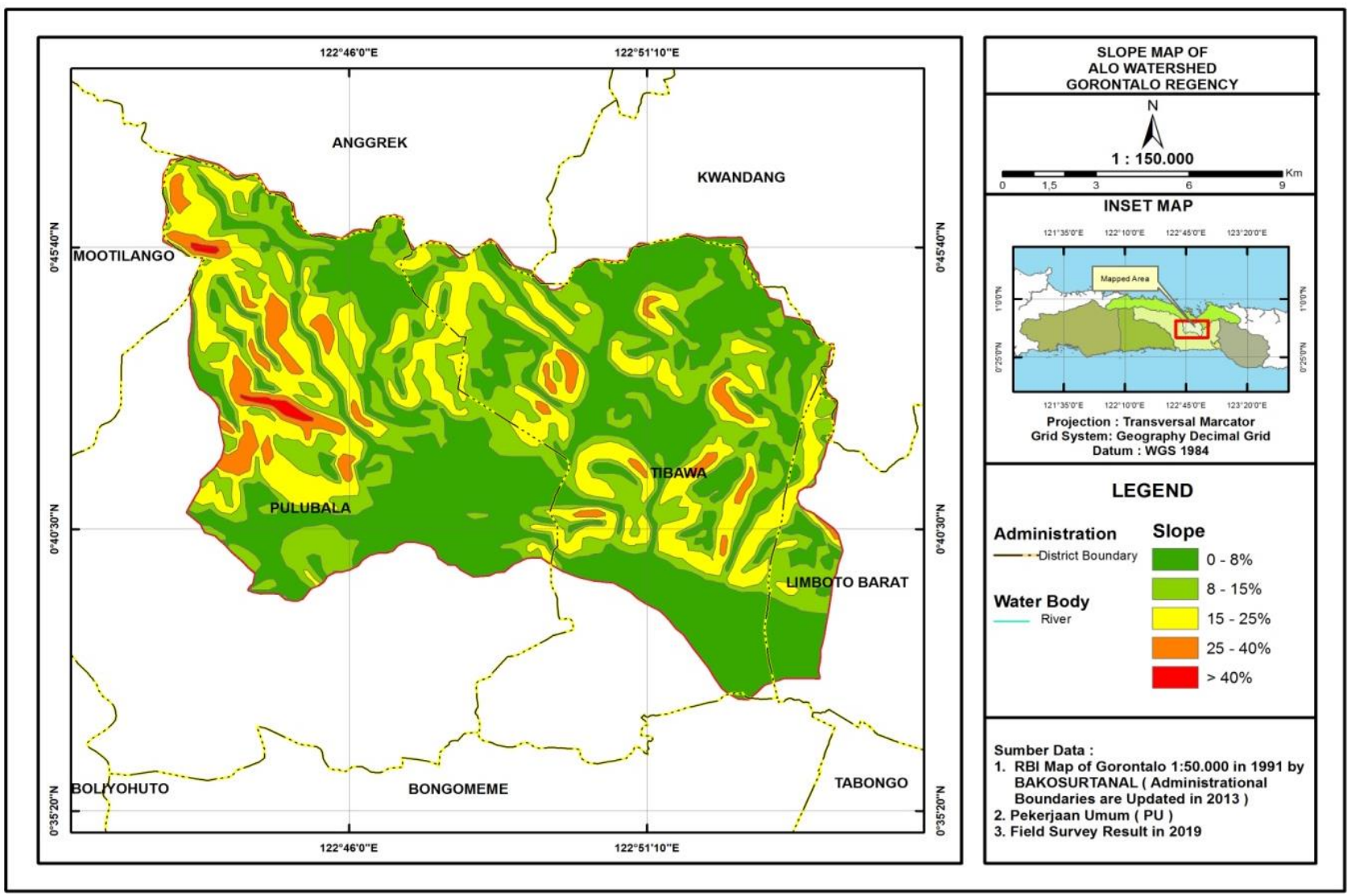

Figure 6. Slope map of Alo Watershed area

\subsection{Types and Characteristics of Soil}

Soil is an important parameter and is one of the main factors for analyzing landslides. At the study site, the texture of the soil is more dominated by loamy sand, making it easier to move material through its slip area. The types of soil found in the study site are alluvial soil, andosol, grumosol, latosol, podsolite, and renzina. It is presented in (Table 4).

Stable land depends on the good and condition of vegetation and has not been overexploited which has an impact on turning land into critical land and susceptible to erosion. Landslides that caused by damaged soil conditions can be minimized by conserving the land. Here is the distribution of soil types found in the Alo watershed area.

The structure and texture of the soil can affect the stability of the sliding plane on the land so that it can cause soil movement. Land damage is affected by the condition of vegetation that has been overexploited which turns the land intocritical land and susceptible to erosion. The characteristics and distribution of land in the Alo watershed are presented in (Figure 7).

\subsection{Community Activities on Land Use}

The land use condition based on the field survey shows that there is land use by converting the function of hilly land into dry land agriculture. The considerable number of people who do not comply with the management and use of land can cause land damage and land degradation. The degradation

Table 4. Distribution of rock types in Alo Watershed

\begin{tabular}{llll}
\hline No & Soil Type & Area $(\mathrm{Ha})$ & Percentage (\%) \\
\hline 1 & Aluvial & 1140.2 & 4.7 \\
2 & Andosol & 13821.3 & 57.1 \\
3 & Grumosol & 4244.3 & 17.5 \\
4 & Litosol & 1593.1 & 6.6 \\
5 & Podsolik & 3271.0 & 13.5 \\
6 & Renzina & 149.4 & 0.6 \\
\hline Total & & 24219.5 & 100 \\
\hline
\end{tabular}




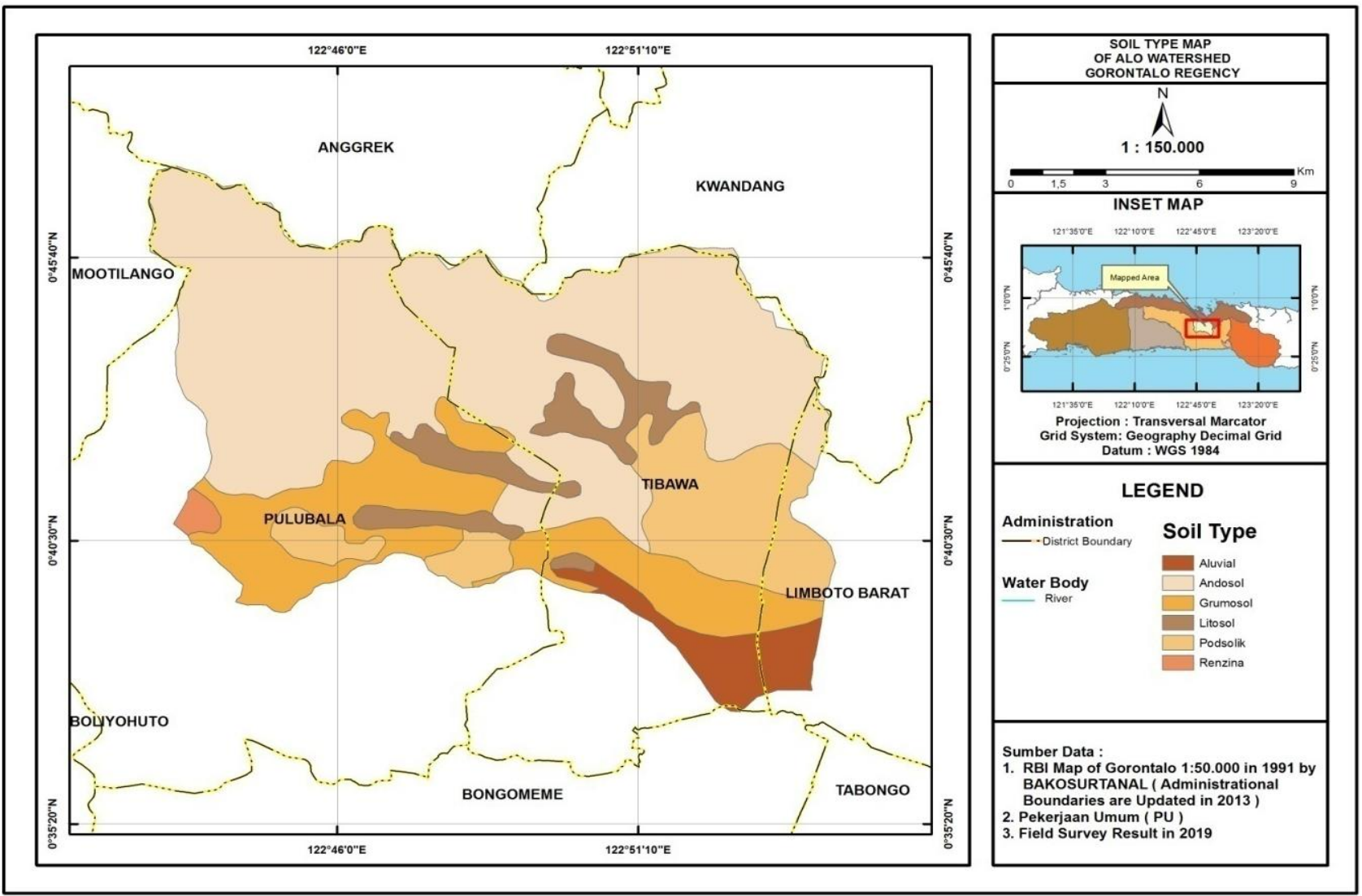

Figure 7. Distribution map soil type characteristics

can be proven by the amount of eroded land by light to severe erosion. A large amount of land management in hilly areas contributes to the instability of land durability in maintaining its consistency to $t$ he carrying capacity of soil material loads which in the end causes landslides. The role of land conversion has an impact on the loss of vegetation in the hills of Alo watershed which is able to withstand soil stability against the slope that can accelerate the occurrence of landslides. Here are some documentations of hills that have experienced land conversion (Figure 8).
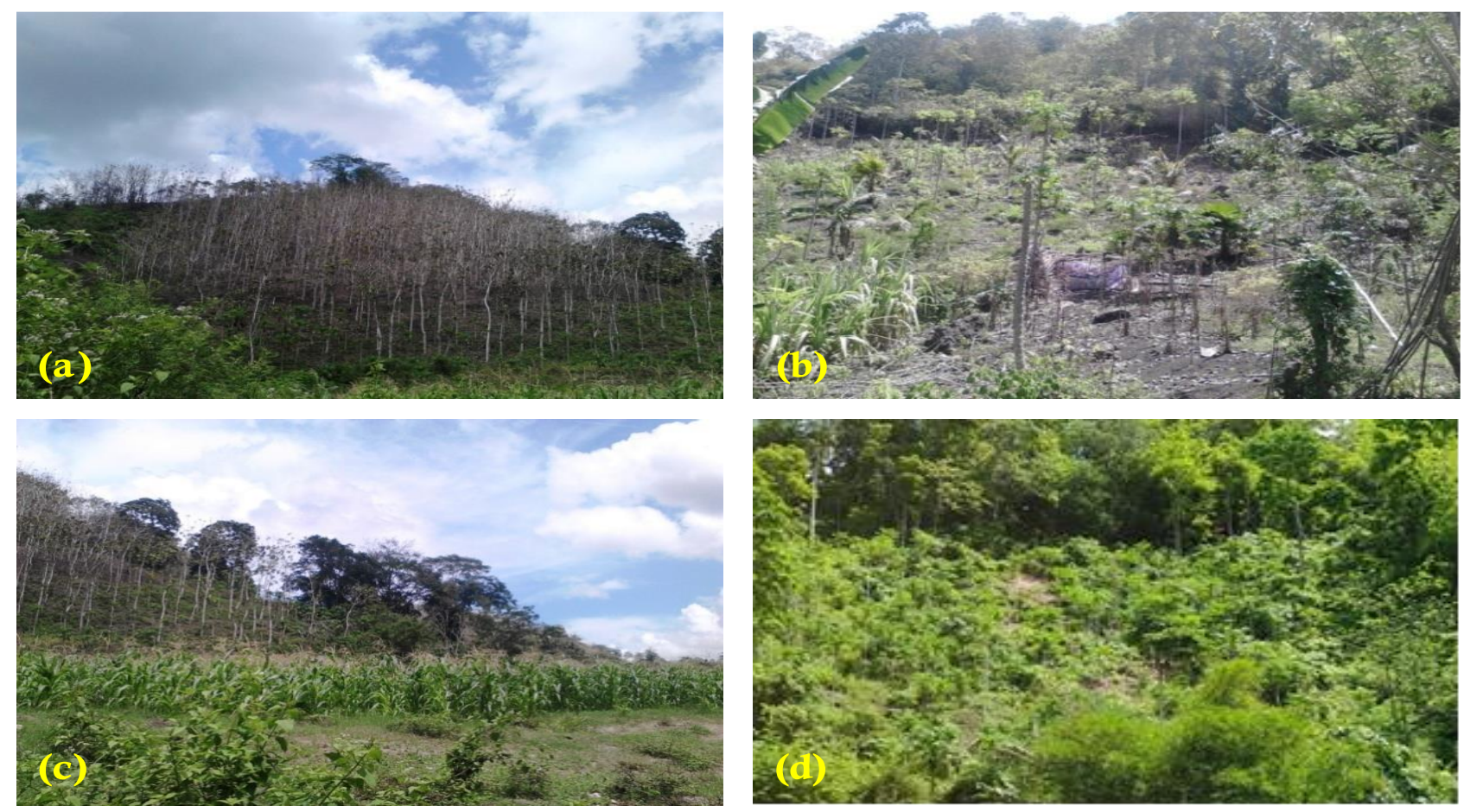

Figure 8. Conditions for land use in the Alo Watershed; (a) White teak cultivation, (b) Papaya plants in slope $>30 \%$, (d) Corn plants on the river's edge, (d) Papaya plants in slope $>35 \%$. 


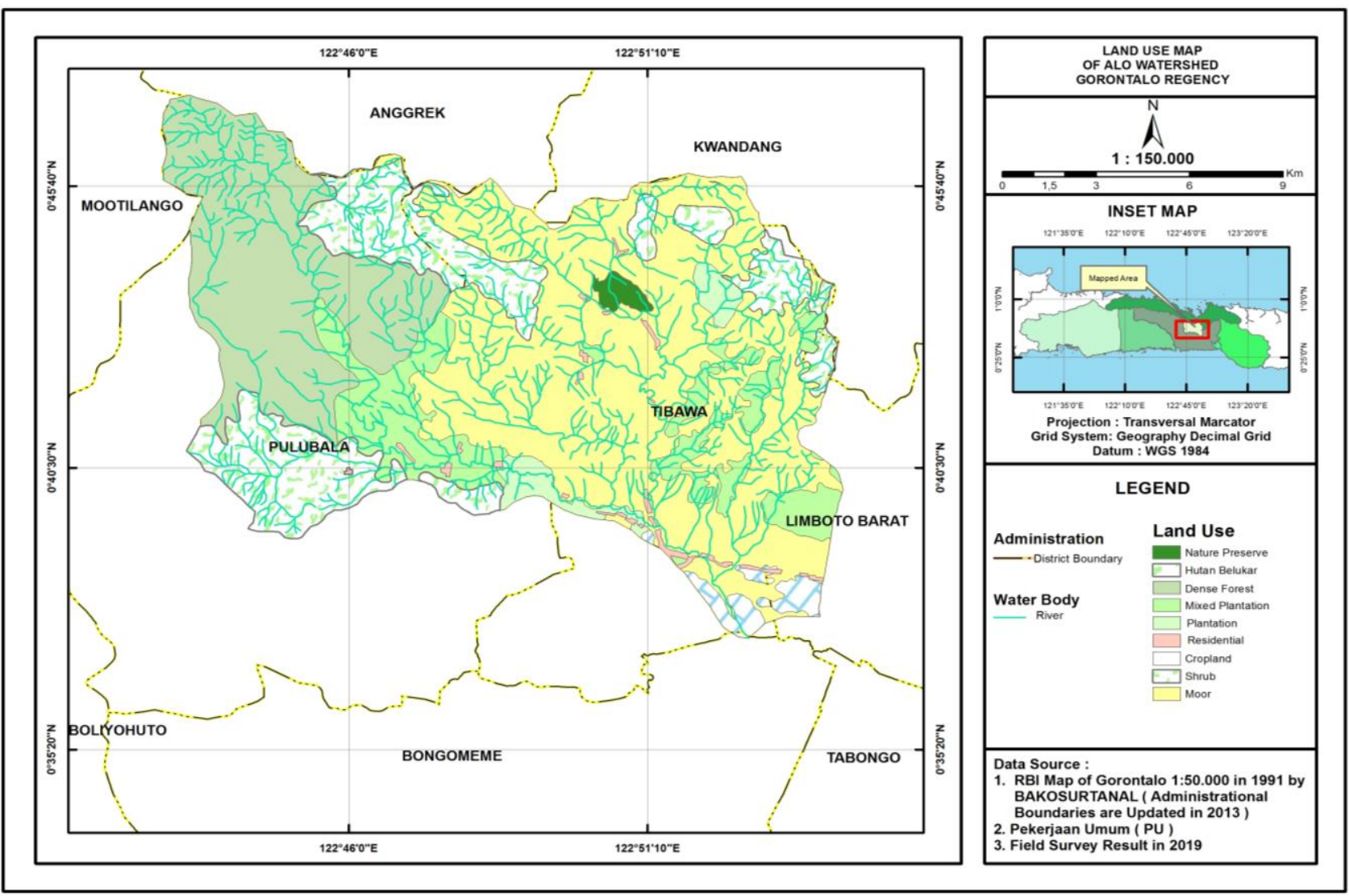

Figure 9. Distribution of characteristics of land use in the Alo Watershed

Community activities in the form of conversion and land use can be converted into maps and digital spatial information (Awawdeh, ElMughrabi, \& Atallah, 2018). Figure 9 explains the survey results that were converted into land use maps. Landslides are very closely related to community activities in utilizing land that is far from the principles of local wisdom. Wisdom in farming by considering the principle of eco-efficiency can help the stability of the Alo Watershed. The increasing needs of the community in the Alo watershed who work as farmers are in line with the continuous increase in land use, which causes the exploitation of hilly land, buffer zones, and forests as an expansion of the land property. The lack of guidelines on the socio-economic activities of the community gives an impact on land conversion activities that continue to increase. Thus the role of the community in excessively exploiting natural resources can accelerate land degradation and accelerate landslides. In other words, land use that is not comparable to conservation-based maintenance has an impact on decreasing land carrying capacity.

The results of the study show that landslides are very difficult to discuss with community activities in utilizing land that is far from the principles of local wisdom. Wisdom in farming by considering the principle of eco-efficiency can help the stability of the Alo Watershed. The increasing needs of the community in the Alo watershed who work as farmers through an increase in the land that continues to occur, so that the use of hilly land, buffer zones, and forests as land for the encroachment of agricultural products. There is no socio-economic activity of the community in land conversion activities that continue to increase. Thus the role of the community in exploiting excessive natural resources can reduce the quality of land by increasing landslides. In other words, the land allocation that is not proportional to the budget is based on its expansion. Landslides can be overcome by increasing regional capacity by integrating communities as controllers in improving the quality of carrying capacity on a conservation-based land (Sari, Innaqa, \& Safrilah, 2017).

\subsection{Spatial Analysis in Determining Landslide Risk Zones}

Landslide maps have characteristics that are fluactive from mass to mass, do not have real-time trends and these disasters cannot be predicted through warnings here such as hydrometeorological disasters and tsunami events, the statement explained by the World Bank and United Nations, 2010. Landslide vulnerability maps in general can provide information about the level of disaster risk of an 


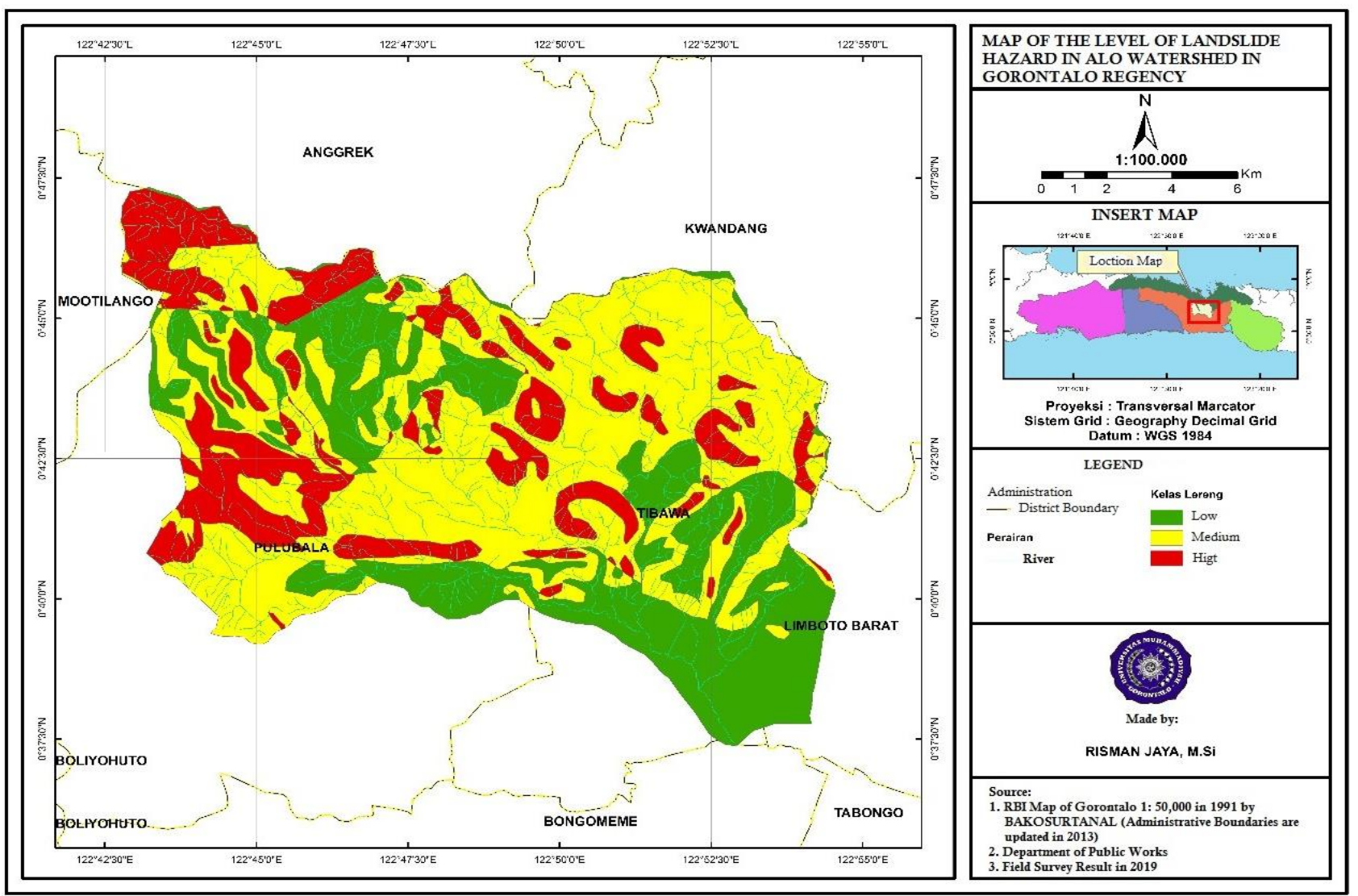

Figure 10. Landslide risk distribution map in the Alo Watershed

area against a longer disaster by classifying it into categories (low, medium and high). Thus, a prediction of past events can be made in the future (Drazba et al., 2018).

The results of spatial analysis (Figure 10) were carried out using scoring and overlay method based on 5 physical parameters such as; rainfall, slope, soil type, geological characteristics, and land use. It generates three categories of hazard levels. "Low" category covers 7171.8 ha, "medium" category covers 12008.7 ha, and the "high" category covers 5039.5 ha. The main factors that influence landslide in Alo watershed are slope, rock characteristics and land use. Landslides are geological disasters that can damage physical conditions and can cause casualties. Landslides have an impact on social problems that are the effects of damage caused by the disaster (Drazba et al., 2018)

\subsection{Community Perception}

In general, the people in the Alo watershed area do not fully understand the landslide event, both in terms of knowledge, impacts, mitigation and how to control it. This can be interpreted based on the results of questionnaires distributed to residents in Alo watershed. In terms of knowledge, 78.11\% of the community knows the landslide occurrence and $21.89 \%$ of them who do not know about landslide occurrence (Haspia et al., 2016). Thus, $21.89 \%$ of the community in Alo watershed who do not know and do not understand landslide is still becoming the focus and target center for socialization about disasters. Hence, the community in Alo watershed can comprehensively understand disaster and victims of disaster can be kept at a minimum.

\section{Conclusion}

The result shows that the spatial distribution of landslide vulnerability includes three categories. "Low" category which covers 7171.8 ha or $29.6 \%$, "Medium" category which covers 12008.7 ha or 49.5\% "high" category which covers 5039.5 ha, which distributed across the Alo watershed with an area of 24,221 ha. The types of landslides that occurred in Alo watershed are rotational landslides, creep landslides and collapsed rock slides. Thus, the Government's cooperation with the community of Alo Watershed related to the anticipation of landslides occurrences is urgently needed to reduce the number of casualties caused by landslide occurrence. 


\section{Acknowledgment}

We would like to thank the Ministry of Technology and Higher Education for funding this research. We would also like to thank Universitas Muhammadiyah Gorontalo for having been a place for us to devote as lecturers and researchers.

\section{Reference}

Adininggar, F. W., Suprayogo, A., \& Wijaya, A. P. (2016). Jurnal Geodesi Undip April 2016. Jurnal Geodesi Undip, 5(April), 2010-2014.

Annisa, J., Sutikno, S., \& Rinaldi. (2015). Analisis Daerah Rawan Longsor Berbasis Sistem Imformasi Geografis (Studi Kasus : Kabupaten Lima Puluh Kota, Sumatera Barat). Jurnal Online Mahasiswa Fakultas Teknik Universitas Riau, 2(2), 1-8.

Asiki, M. I., Maryati, S., \& Akase, N. (2019). Analisis Tingkat Kerentanan Longsor Daerah Muara Sungai Bone Kota Gorontalo. Jambura Geoscience Review, 1(2), 87-101. https://doi.org/10.34312/jgeosrev.v1i2.2474

Awawdeh, M. M., ElMughrabi, M. A., \& Atallah, M. Y. (2018). Landslide susceptibility mapping using GIS and weighted overlay method: a case study from North Jordan. Environmental Earth Sciences, 77(21), 0. https://doi.org/10.1007/s12665-018-7910-8

Drazba, M. C., Yan-Richards, A., \& Wilkinson, S. (2018). Landslide Hazards in Fiji, managing the risk and not the disaster, a literature review. Procedia Engineering, 212 (2017), 1334-1338. https://doi.org/10.1016/j.proeng.2018.01.172

Froude, M. J., \& Petley, D. N. (2018). Global fatal landslide occurrence from 2004 to 2016. Natural Hazards and Earth System Sciences, 18(8), 2161-2181. https://doi.org/10.5194/nhess-18-2161-2018

Haspia, Lihawa, F. Yusuf, D. (2016). Sebaran Spasial Kondisi Sosial Ekonomi Masyarakat di Das Alo Provinsi Gorontalo, Universitas Negeri Gorontalo.

Highland, L.M. Bobrowsky, P. (2008). The Landslide Handbook - A Guide to Understanding Landslides. Circular: U.S. Department of the Interior, U.S. Geological Survey.

Jaya, R., Pomalingo, N., \& Lihawa, F. (2016). Sebaran Spasial Lahan Kritis Di Daerah Aliran Sungai Alo Kabupaten Gorontalo. 470-478. Surakarta: Universitas Sebelas Maret,BIG,KLHK.

Muntohar. (2010). Tanah Longsor Analisis Prediksi Mitigasi (1st ed.). Yogyakarta: Universitas Muhammadiyah Yogyakarta.

Sari, D. A. P., Innaqa, S., \& Safrilah. (2017). Hazard, Vulnerability and Capacity Mapping for Landslides Risk Analysis using Geographic Information System ( GIS ) Hazard, Vulnerability and Capacity Mapping for Landslides Risk Analysis using Geographic Information System ( GIS ). Materials Science and Engineering. https://doi.org/10.1088/1757-899X/209/1/012106

Setiawan, B., Sudarto, \& Putra, A. N. (2017). Pembuatan Peta Potensi Lahan Berdasarkan Kondisi Fisik Lahan Menggunakan Metode Weighted Overley. Jurnal Tanah Dan Sumberdaya Lahan, 4(2), 567-576.

Susanti, I., Sipayung, S. B., Cholianawati, N., Rahayu, S. A., S., L. S., \& Sunarya, R. (2012). Pengaruh Curah Hujan Terhadap Potensi Longsor di Daerah Aliran Sungai (DAS) Citarum. Sains Atmosfer Dan Aplikasinya, (Prosiding SNSAA 2012), 978-979. 